\title{
The Effect of Work Load and Quality Work Life on the Performance of Police Members in Indonesian Police Headquarters Korlantas with Job Satisfaction as Intervening Variables
}

\author{
Siska Wirastuti1, I Ketut R Sudiarditha'2, Henry Eryanto³, Juhasdi Susono ${ }^{4}$, \\ Amiruddin $\mathrm{K}^{5}$ \\ 1,2,3 Universitas Negeri Jakarta, Indonesia \\ ${ }^{4}$ Sekolah Tinggi Agama Islam Al Furqan Makassar, Indonesia \\ ${ }^{5}$ Universitas Islam Negeri Alauddin Makassar, Indonesia
}

Corresponding Author: Juhasdi Susono @juhasdimm@gmail.com*

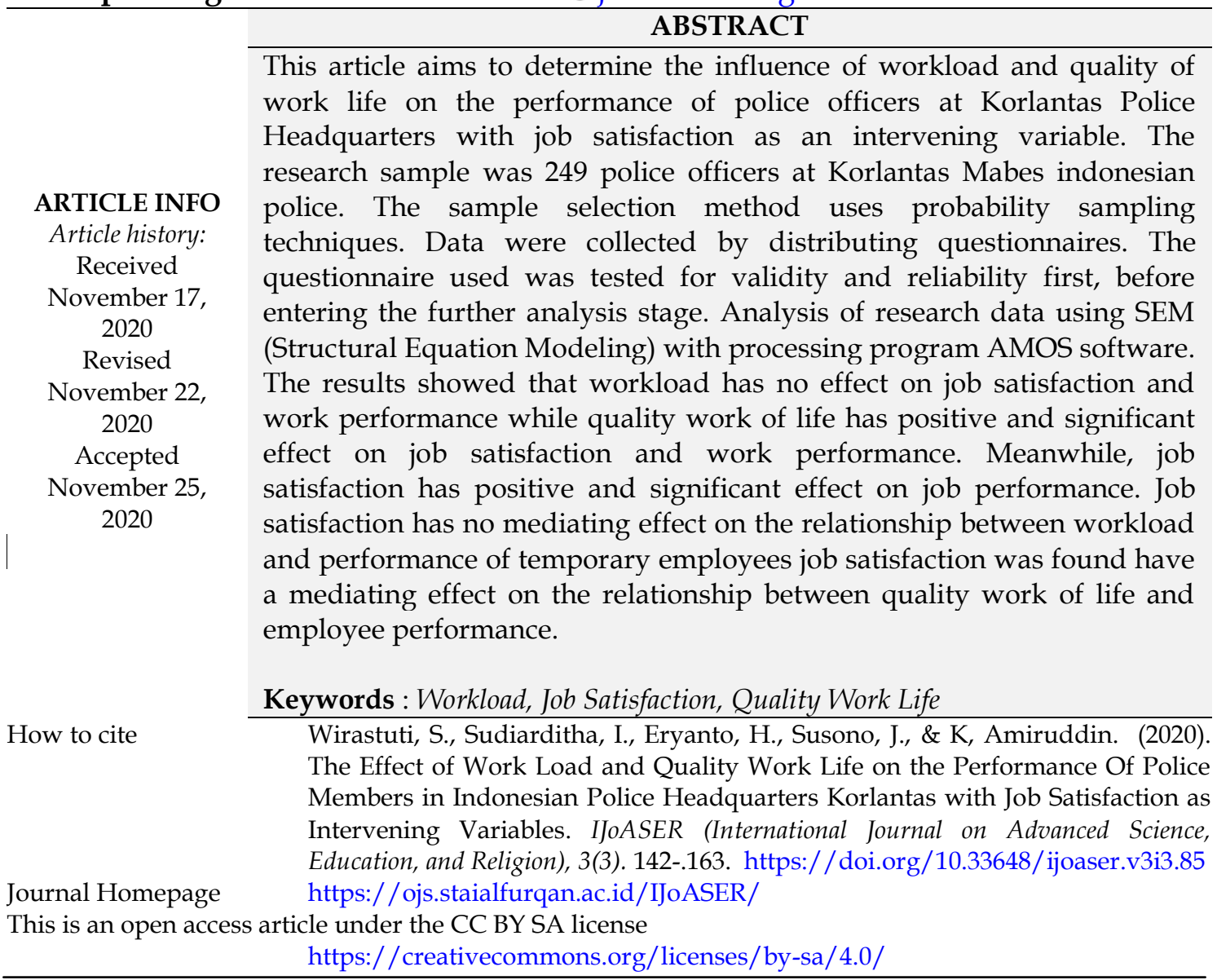

\section{INTRODUCTION}

The police are one of the state institutions as the front line of guarding the community with the implementation of their duties which are quite heavy and tend to be carried out individually in the field and they are required to be able to make decisions individually in facing real situations. The main duties of the police are tasks that must be carried out or carried out by a police institution, thus the institutional duties carried out by members of the police can be interpreted as a form or type of work that has a large responsibility. Currently, the bureaucratic reform within the National Police is continuing, including instrumental, structural, and cultural reforms. 
Instrumental reform will include vehicles and technology to support Indonesian Police's duties in the field. Because it is hoped that Indonesian Police's duties will be better than before, so they must maintain the equipment they have in order to function properly and can help police performance in the field. Then based on Presidential Regulation No.52 dated 4 August 2010 Dit. Then the Police became the Traffic Police Corps (Korlantas Indonesian Police). Korlantas Indonesian Police has a direct position under the Chief of Police, tasked with fostering and carrying out traffic functions including public education, law enforcement, assessing traffic problems, registering and identifying drivers and motorized vehicles as well as road patrols. The existence of Korlantas itself is expected to be able to make drivers and motorized vehicles more organized so that accidents on the road can be avoided. And here is the performance of the Korlantas Indonesian Police for the last 4 years.

\section{Figure 1. Graph of Korlantas Performance}

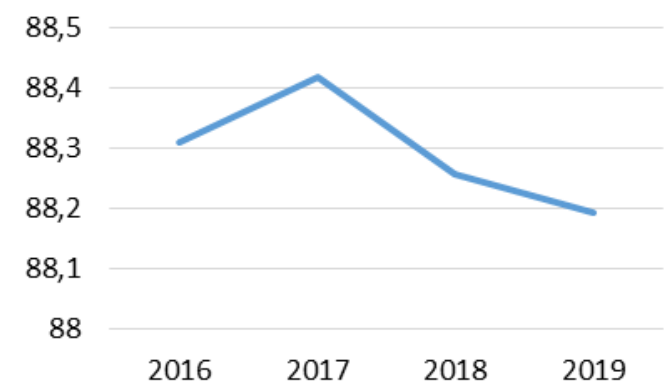

Source: Korlantas Indonesian Police (2019)

Based on Figure 1 above, it can be seen that the performance of the traffic police has fluctuated and tended to decline in the last two years, the researcher tried to make an initial questionnaire to find out the reasons behind the fluctuating performance of traffic police at the Traffic Police Corps Headquarters Police.

Figure 2. Questionnaire for Fluctuating Reasons

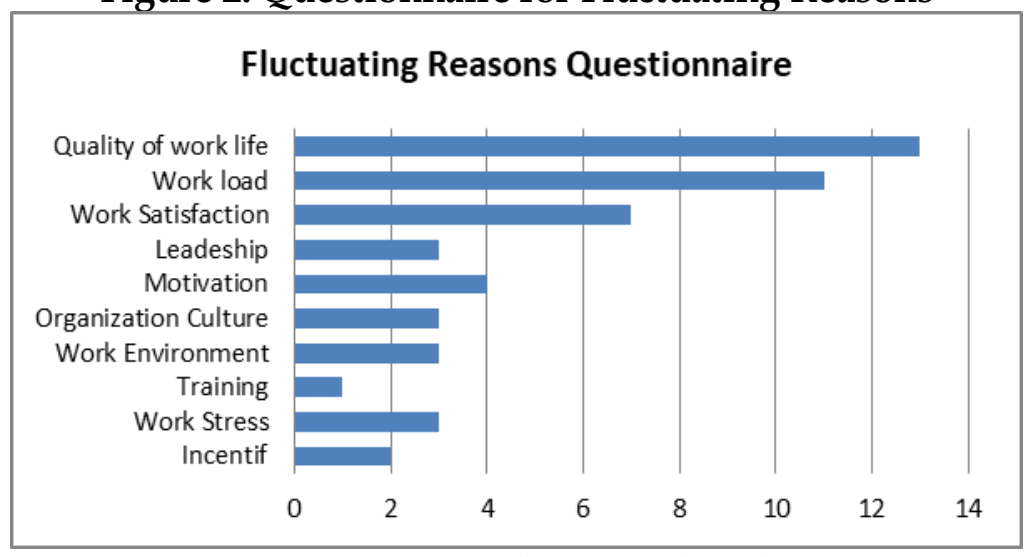

Source: Researcher Data (2020)

Based on Figure 2 above, the results of the quality work life questionnaire are one of the factors that affect performance. The work environment of traffic police officers at Korlantas, who are mostly on the streets, is one of the causes of quality work life to affect organizational performance. An organization that recognizes the role of human resources and productivity improvement and appreciates the strength of a 
workforce that is committed, especially directed at resources and management, to a development environment where workers can contribute to improved performance at maximum capacity. Efforts like this are known as quality work life or employee engagement strategies (Lilian M. de Menezes 2012; Wibowo, 2009). Quality of work life also affects productivity (Kossen, 1993). The thing related to the next performance is the excessive workload of the traffic police at Korlantas. An increased workload sometimes has problems, including employees who are prone to burnout due to the workload. Robbin (2003) Ming-Chun Tsai1 et.al. (2018), Alfani (2018) stated that positive and negative workload is a problem of perception. Korlantas members who have a high workload are required to work to meet the predetermined targets, namely as an information and communication control center that regulates traffic in Indonesia. But in reality Korlantas members often do work outside of the above work, including (a.) Maintenance of public order, (b) securing demonstrations and vital objects, controlling the masses, negotiating and searching and rescuing (Pasaribu \& Indrawati, 2016; Omar Durrah et al., 2016; Wahyuni \& Irfani, 2019).

Excess workload and organizational climate that is less conducive will affect employee job satisfaction. High workload has a negative effect on job satisfaction (Mustapha and Ghee, 2013). In addition to the phenomena related to organizational performance, this research is also based on the existence of a number of research gaps, namely: First, previous studies on organizational performance were mostly carried out in other service industries while in the law enforcement industry it was still relatively small (Iskandar \& Sembada 2012; Sitepu, 2013; Hersanti et al., 2020). Along with the high accident fatality rate, it is very important to conduct research on the performance of the organization, especially in the law enforcement agencies of the National Police Corps, so that an appropriate strategy can be formulated to improve organizational performance and reduce the number of accidents (Hadi \& Rahman 2018; Fathiyah, Firdaus \& Putra, 2017). Second, the results of previous studies still show different or inconsistent results for several influences between variables.

Based on the explanation of the background of the problem above, there are differences in the findings and the results of the pre-survey conducted by the researcher, the researcher is interested in researching, reviewing and reconfirming the relationship of each variable to different situations and conditions that are more or less the same and raising the theme "Effect Workload and Quality of Work Life on the Performance of Korlantas at National Police Headquarters with job satisfaction as an intervening variable. "

Mangkunegara (2016) stated that the definition of performance is the quality and quantity of work achieved by an employee or an employee in carrying out their duties in accordance with the responsibilities assigned to them. Another opinion explained by Sutrisno (2016) that performance is a person's success in carrying out a task, the work results that can be achieved by a person or group of people in an organization according to their respective authority and responsibility or about how someone is expected to function and behave in accordance with tasks that have been assigned to him and the quantity, quality, and time used in carrying out the task. Based on the definitions of the experts above, it can be concluded that performance is the work achieved by employees in an organization in accordance with the authority and responsibilities given by the organization in an effort to achieve the vision, mission and goals of the organization. Performance is a series of activities that illustrate the extent to which the results achieved by employees in carrying out their duties and responsibilities in the form of public accountability, can be in the form of successes or 
deficiencies that have occurred. The results of a job can be in the form of goods or services and employee performance can be seen from the goods or services produced by the employee.

\section{METHOD}

This research has the object of research, namely members of the police on duty at Korlantas Indonesian Police. The variables studied consisted of 4 variables, namely: performance as the dependent variable, workload and work life quality as independent variables and job satisfaction as an intervening variable. The population will be used in this study are members of the Police in the Indonesian National Police Headquarters 2019. The data source of this research is the result of filling out a questionnaire that will be given to members of the Police at the Indonesian National Police Headquarters. According to Hair et al. (1998), the maximum sample size is 10 (ten) times the number of question items (indicators) contained in the questionnaire, so that if the question items are 38 , the sample size is $38 \times 10=380$ respondents. This number is an initial determination sample only, because if abnormal data appears from the data, the sample size is no longer appropriate. Sampling in this study was carried out by taking random samples from police officers of Korlantas Indonesian Police Headquarters. In this study, the authors use the basis for measuring the performance variables adopted from the study of Prawirosentono (2008), while the workload variable was adopted from the study Hart and Staveland (1988). The measurement of the quality of work life variable was adopted from the research of Walton (1975) in Kanten (2012), while the variable was adopted from Luthans' research (2006).

\section{RESULT AND DISCUSSION Hubungan Kausalitas}

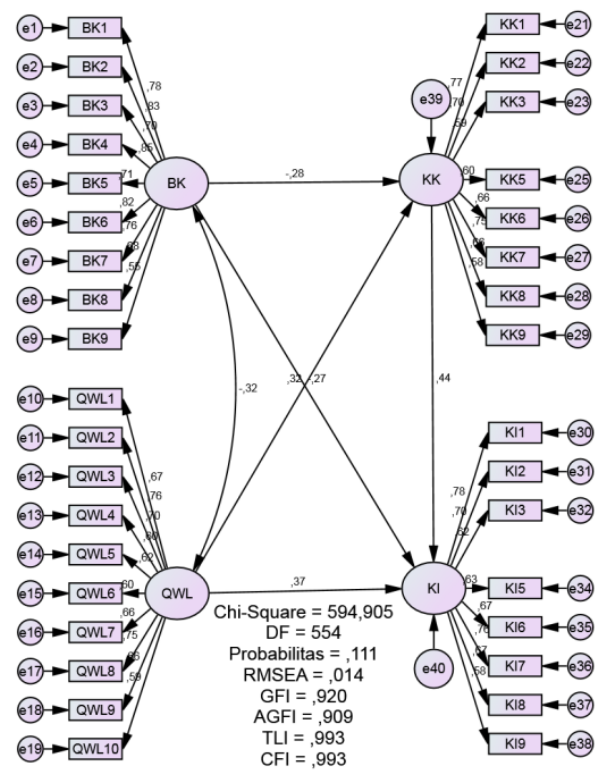

Sumber: Result from Researchers (2020)

\section{Figure 3 Diagram Alur Penelitian}

Based on the picture above, the shape in the circle of the research flowchart is an observed variable using a questionnaire, such as the workload variable with 9 indicators $\mathrm{BK} 1, \mathrm{BK} 2, \mathrm{BK} 3, \mathrm{BK} 4, \mathrm{BK} 5, \mathrm{BK} 6, \mathrm{BK} 7, \mathrm{BK} 8$, and $\mathrm{BK} 9$. Each of the indicator 
items has standard errors e1, e2, e3, e4, e5, e6, e7, e8 and e9. This also applies to constructs - other constructs are formed from each of the indicators. In the variable quality of work life with 10 indicator items QWL1, QWL2, QWL3, QWL4, QWL5, QWL6, QWL7, QWL8, QWL9, QWL10 and every 10 indicators there are standard errors e10, e11, e12, e13, e14, e15, e16, e17, e18, e19. On the job satisfaction variable with 8 indicator items $\mathrm{KK} 1, \mathrm{KK} 2, \mathrm{KK} 3, \mathrm{KK} 5, \mathrm{KK} 6, \mathrm{KK} 7, \mathrm{KK} 8, \mathrm{KK} 9$ of the 8 indicators have standard errors of e21, e22, e23, e25, e, 26, e27, e28 and e, 29. Whereas the performance variable with 8 indicator items is KI1, KI2, KI3, KI5, KI6, KI7, KI8, KI9 with standard errors of each of the 8 indicators, these are e30, e31, e32, e, 34, e35, e36, e37, e38. Researchers use the AMOS v.24 software in the AMOS application, the effect of quality is simply depicted in a flowchart and then the program language converts the image into an equation, then the equation becomes an estimate.

\section{Validity and Reliability}

Test In testing the validity carried out in this study to determine how appropriate (valid) and whether the statements in this study. The basis for making a decision can be seen by comparing the value of Corrected Item-Total Correlation compared to the value of the $\mathrm{R}$ Table with a level of 0.05 of 0.139 . If the results of Corrected Item Total Correlation $>0.139$ then the data is valid, and vice versa if the results of Corrected Item Total Correlation $<0.139$ are invalid data. After doing the validity test, the researcher tested the reliability. By comparing the alpha coefficient value by comparing the results of the Cronbach's Alpha value $>0.7$, the data is reliable and vice versa. Below are the results of the validity and reliability of this study.

Table 1. Reliability and Validity Test Results of Questionnaire

\begin{tabular}{|c|c|c|c|}
\hline $\begin{array}{c}\text { Constructs / Latent } \\
\text { Variable }\end{array}$ & $\begin{array}{c}\text { Reliability ((Cronbach's } \\
\text { AlphaCronbach's Alpha) })\end{array}$ & $\begin{array}{c}\text { Item } \\
\text { (Indicator) }\end{array}$ & $\begin{array}{c}\text { Corrected Item } \\
\text { Total Correlation }\end{array}$ \\
\hline \multirow{3}{*}{} & 0.902 & BK1 & 0.742 \\
\hline & 0.899 & BK2 & 0.798 \\
\hline Workload & 0.908 & BK3 & 0.663 \\
\hline & 0.898 & BK4 & 0.805 \\
\hline & 0.907 & BK5 & 0.672 \\
\hline & 0.900 & BK6 & 0.784 \\
\hline & 0.904 & BK7 & 0.716 \\
\hline & 0.909 & BK8 & 0.648 \\
\hline & 0.917 & BK9 & 0.516 \\
\hline & 0.887 & QWL1 & 0.631 \\
\hline & 0.882 & QWL2 & 0.710 \\
\hline & 0.885 & QWL3 & 0.659 \\
\hline & 0.890 & QWL4 & 0.571 \\
\hline
\end{tabular}




\begin{tabular}{|c|c|c|c|}
\hline & 0.889 & QWL5 & 0.588 \\
\hline \multirow[t]{9}{*}{ Quality of Work Life } & 0.890 & QWL6 & 0.567 \\
\hline & 0.887 & QWL7 & 0.618 \\
\hline & 0.883 & QWL8 & 0.702 \\
\hline & 0.887 & QWL9 & 0.617 \\
\hline & 0.891 & QWL10 & 0.563 \\
\hline & 0.884 & QWL11 & 0.674 \\
\hline & 0.845 & KK1 & 0.699 \\
\hline & 0.850 & KK2 & 0.642 \\
\hline & 0.859 & KK3 & 0.546 \\
\hline \multirow[t]{9}{*}{ Job Satisfaction } & 0.857 & KK5 & 0.560 \\
\hline & 0.853 & KK6 & 0.615 \\
\hline & 0.846 & KK7 & 0.695 \\
\hline & 0.854 & KK8 & 0.599 \\
\hline & 0.860 & KK9 & 0.542 \\
\hline & 0.852 & KI1 & 0.723 \\
\hline & 0.858 & KI2 & 0.656 \\
\hline & 0.865 & KI3 & 0.574 \\
\hline & 0.865 & KI5 & 0.578 \\
\hline \multirow{4}{*}{$\begin{array}{l}\text { Employee } \\
\text { Performance }\end{array}$} & 0.860 & KI6 & 0.636 \\
\hline & 0.854 & KI7 & 0.711 \\
\hline & 0.862 & KI8 & 0.612 \\
\hline & 0.870 & KI9 & 0.521 \\
\hline
\end{tabular}

Source: Processed by Researchers (2020)

Based on the table above shows that all indicators (observed) are valid, because the results on the Corrected Item Total Correlation $>\mathrm{r}$ table (0.139). It can be said that all indicators (observed) are suitable to be used as indicators of constructs (latent variables). While the reliability results (Cronbach's alpha) have a value of $>0.7$, it can be concluded that the research variables (constructs) in the form of workload variables, quality of work life, job satisfaction and overall performance are reliable or have high reliability. 


\section{Data Normality Test Normality}

test is one of the requirements for processing SEM modeling that will be made in this study. In assessing the normality of the data in this study, it was carried out by looking at the Asymp Sig $>0.05$, so the data were normally distributed. Following below are the results of the normality test in this study:

Tale 2 Uji Normalitas

\begin{tabular}{|ll|r|}
\hline & & Unstandardized Residual \\
\hline $\mathrm{N}$ & & 380 \\
Normal Parameters $\mathrm{a}, \mathrm{b}$ & Mean &, 0000000 \\
& Std. Deviation & 2,89048269 \\
Most Extreme Differences & Absolute &, 116 \\
& Positive &, 065 \\
& Negative &,- 116 \\
Kolmogorov-Smirnov Z & & 2,267 \\
Asymp. Sig. (2-tailed) &, 160 \\
\hline a. Test distribution is Normal. & \\
b. Calculated from data. &
\end{tabular}

The results output above, the Asymp Sig in this study is 0.16>0.05, it can be assumed that the data is normally distributed, and meets the requirements for further testing.

\section{Hypothesis}

Test Test Explanatory Factor Analysis (EFA)

in factor analysis aims to determine how much influence the independent variables have on the dependent variable. As a basis for decision making, it can be seen in the output value of the Kaiser Mayer Olkin Measure of Sampling Adequacy (KMO MSA) and the significant value on the Bartlett's Test of Spherincity. Based on the results of the KMO MSA value in the study below, it is $0.94>0.50$ and a significant value of 0.00 $<0.05$. So overall data analysis in this study can be continued because it has met the first requirements. Below is the KMO MSA results in this study are:

Test Confirmatory Factor Analysis (CFA) test the validity of this study were tested using AMOS program to view a table of output estimate by comparing the p-value with an alpha of 0.05 , when the results of $\mathrm{p}$ - value is denoted by *** or $\leq 0.05$ then the indicator is declared valid. Besides being able to compare the p-value with alpha, the CFA can be seen in the CFI output results $>0.90$ so the data is valid. Then it can be seen in the GFI output results $>0.90$, the data is declared valid, it can also be seen in the TLI output results $>0.90$, the data is declared valid and RMSEA $<0.05$ the data is declared valid. 


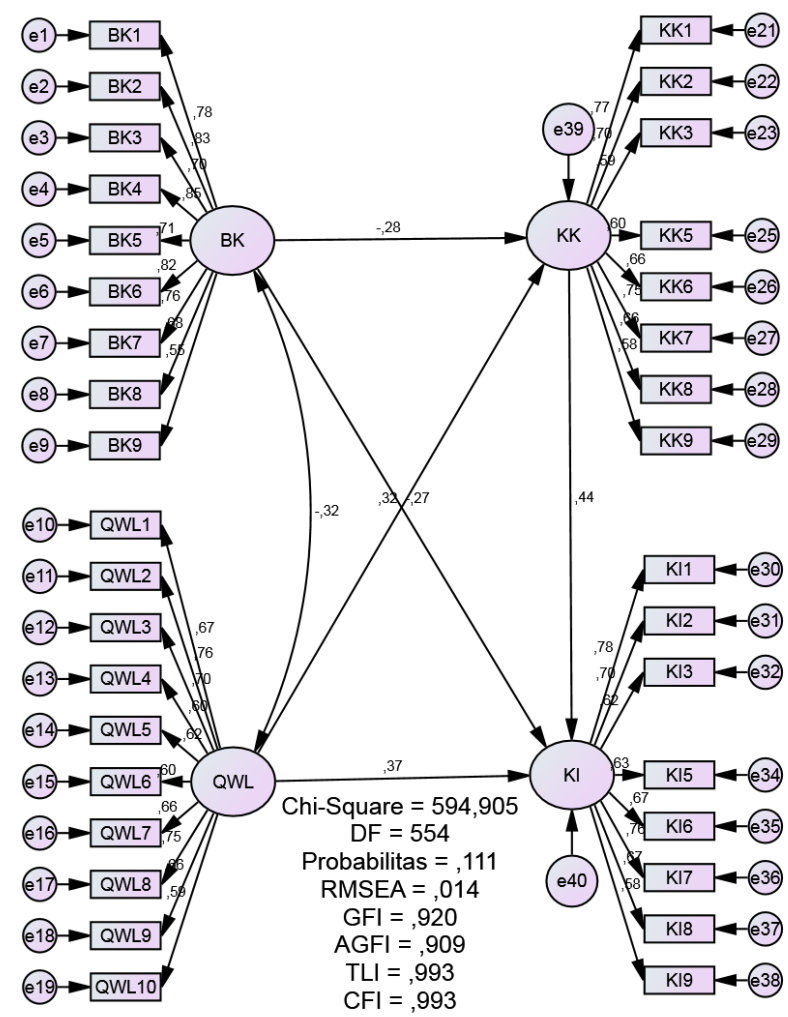

Figure 4 Confirmatory Factor Analysis (Full Model)

The results of the image above are the results of testing for Confirmatory Factor Analysisusing AMOS, based on the results above indicate that the constructs in this research model are fit. It can be seen from the results of the P Value, CMIN, RMSEA, GFI, TLI and CFI. Here below are the results output in the table estimate in this study:

Table 3 Model Fit Summary CMINE P Value

\begin{tabular}{|l|rrrrr|}
\hline Model & NPAR & CMIN & DF & P & CMIN/DF \\
\hline Default model & 76 & 594,905 & 554 &, 111 & 1,074 \\
Saturated model & 630 &, 000 & 0 & & \\
Independence model & 35 & 6489,605 & 595 &, 000 & 10,907 \\
\hline
\end{tabular}

Based on the results of the table above, it shows the P value of $0.11>0.05$, so the model in the study is declared fit, according to the basis for decision making. While the CMIN results in this study were 1.07. To strengthen the model in research, it can be seen from the GFI results.

Table 4 Model Fit Summary GFI

\begin{tabular}{|l|rrrr|}
\hline Model & RMR & GFI & AGFI & PGFI \\
\hline Default model &, 026 &, 920 &, 909 &, 809 \\
Saturated model &, 000 & 1,000 & & \\
Independence model &, 205 &, 230 &, 185 &, 217 \\
\hline
\end{tabular}

The output above shows that the GFI value is $0.92>0,90$, it can be concluded that the model in the study is declared fit, in accordance with the basis for decision making, in 
addition to seeing how fit the model in research can look at the results of the TLIoutput and CFI

Table 5 Model Fit Summary TLI \& CFI

\begin{tabular}{|l|rrrrr|}
\hline \multirow{2}{*}{ Model } & $\begin{array}{r}\text { NFI } \\
\text { Delta1 }\end{array}$ & $\begin{array}{r}\text { RFI } \\
\text { rho1 }\end{array}$ & $\begin{array}{r}\text { IFI } \\
\text { Delta2 }\end{array}$ & $\begin{array}{r}\text { TLI } \\
\text { rho2 }\end{array}$ & CFI \\
\hline Default model &, 908 &, 902 &, 993 &, 993 &, 993 \\
Saturated model & 1,000 & & 1,000 & & 1,000 \\
Independence model &, 000 &, 000 &, 000 &, 000 &, 000 \\
\hline
\end{tabular}

From the results output above shows that the TLI value is $0.99>0.90$ and the results of the CFI value are $0.99>0.90$, which means that the model in the study is declared fit, because it is in accordance with the basis for decision making. To strengthen this research, it can be seen that the RMSEA value in this study.

Table 6 Model Fit Summary RMSEA

\begin{tabular}{|l|rrrr|}
\hline Model & RMSEA & LO 90 & HI 90 & PCLOSE \\
\hline Default model &, 014 &, 000 &, 022 & 1,000 \\
Independence model &, 162 &, 158 &, 165 &, 000 \\
\hline
\end{tabular}

Overall that the model in the study is fit, but to strengthen a study it can be seen In the RMSEA results, the RMSEA results are $0.01<0.05$, it can be concluded that the model in the study is fit and meets the requirements.

a. Causality Analysis (Structural Equations)

Estimation analysis is carried out in order to know and analyze the full model to see the suitability in the research model and the causality relationship built into the model being tested. The following is the result of the Full Model in this study:

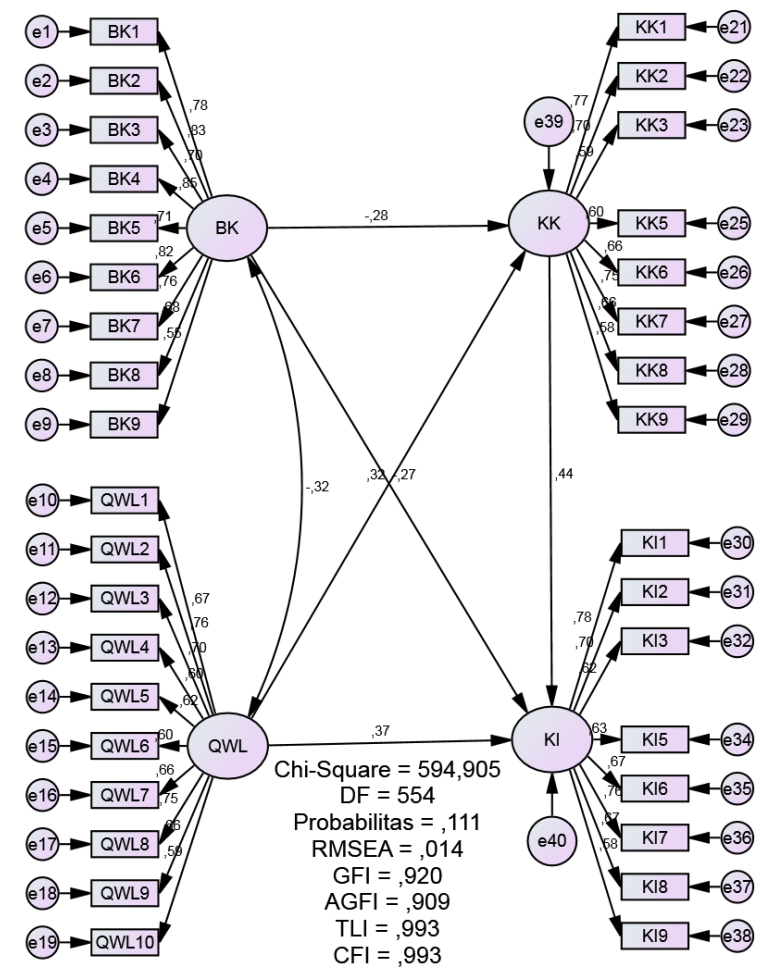

Figure 5 Results of Structural Equation Analysis 
b. Evaluasi Kriteria Ketetapan Model (Goodnes of Fit Model)

From the above image of testing the suitability of the model is evaluated through a review of the various criteria goodnes of fitmodel,to measure in evaluating this criterion along with the limit value(cutvalue)as follows:

Table 7 Test Accuracy Model

\begin{tabular}{|l|c|c|c|}
\hline \multicolumn{1}{|c|}{ Goodnes of Fit Index } & Cut of Value & Estimation Results & Description \\
\hline Chi-Square & $\begin{array}{c}\text { expected to be } \\
\text { small expected } \\
\text { to be small }\end{array}$ & 594,90 & Fit Model \\
\hline P-Value & $>0,05$ & 0,111 & Fit Model \\
\hline CMIN/DF & $<2,00$ & 1,704 & Fit Model \\
\hline GFI & $>0,90$ & 0,92 & Fit Model \\
\hline RMSEA & $<0,08$ & 0,01 & Fit Model \\
\hline TLI & $>0,90$ & 0,99 & Fit Model \\
\hline AGFI & $>0,90$ & 0,90 & Fit Model \\
\hline CFI & $>0,90$ & 0,99 & Fit Model \\
\hline
\end{tabular}

From the output above states that the results of the Chi-Square value are 594.90 with a $P$ value of $0.11>0.05$, it can be concluded that the probability value meets the recommended standard value so that the model is fit. The GFI value is $0.90>0.90$ then the RMSEA value is $0.01<0.05$, then the TLI value is $0.99>0.90$ and the CFI value is $0.99>0.90$. It can be concluded that the results of the analysis are marginally feasible.

a. Hypothesis testing.

Testing is done by looking at the value Critical Ratio in the table below:

Table 8 Hypothesis Test

\begin{tabular}{|c|c|c|c|c|c|c|c|}
\hline & & & Estimate & S.E. & C.R. & $\mathrm{P}$ & Label \\
\hline KK & $<-$ & BK &,- 211 & ,044 & $-4,842$ & $* * *$ & \\
\hline KK & $<--$ & QWL & 315 & ,059 & 5,310 & $* * *$ & \\
\hline KI & $<--$ & $\mathrm{BK}$ & -203 & ,034 & $-6,027$ & $* * *$ & \\
\hline KI & $<--$ & QWL & ,357 & ,049 & 7,254 & $* * *$ & \\
\hline KI & $<-$ & KK & ,429 & ,052 & 8,322 & $* * *$ & \\
\hline BK1 & $<--$ & $\mathrm{BK}$ & 1,000 & & & & \\
\hline BK2 & $<-$ & $\mathrm{BK}$ & ,952 & ,054 & 17,633 & $* * *$ & \\
\hline BK3 & $<--$ & $\mathrm{BK}$ & ,899 & ,063 & 14,187 & $* * *$ & \\
\hline BK4 & $<--$ & BK & 1,048 & 058 & 18,172 & $* * *$ & \\
\hline BK5 & $<-$ & $\mathrm{BK}$ & ,807 & ,056 & 14,494 & $* * *$ & \\
\hline BK6 & $<--$ & $\mathrm{BK}$ & ,861 & ,050 & 17,303 & $* * *$ & \\
\hline BK7 & $<-$ & $\mathrm{BK}$ & ,853 & ,054 & 15,662 & $* * *$ & \\
\hline BK8 & $<--$ & $\mathrm{BK}$ & 710 & ,051 & 13,836 & $* * *$ & \\
\hline BK9 & $<--$ & BK & 630 & 058 & 10,772 & $* * *$ & \\
\hline QWL1 & $<-$ & QWL & 1,000 & & & & \\
\hline QWL2 & $<--$ & QWL & ,971 & ,074 & 13,042 & $* * *$ & \\
\hline QWL3 & $<--$ & QWL & ,889 & ,073 & 12,127 & $* * *$ & \\
\hline QWL4 & $<-$ & QWL & 819 & ,077 & 10,640 & $* * *$ & \\
\hline QWL5 & $<--$ & QWL & 898 & ,082 & 10,951 & $* * *$ & \\
\hline
\end{tabular}




\begin{tabular}{|c|c|c|c|c|c|c|c|}
\hline & & & Estimate & S.E. & C.R. & $\mathrm{P}$ & Label \\
\hline QWL6 & $<--$ & QWL & ,760 & ,072 & 10,560 & $* * *$ & \\
\hline QWL7 & $<--$ & QWL & ,829 & ,072 & 11,534 & $* * *$ & \\
\hline QWL8 & $<--$ & QWL & ,923 & ,072 & 12,875 & $* * *$ & \\
\hline QWL9 & $<--$ & QWL & 911 & 079 & 11,488 & $* * *$ & \\
\hline QWL10 & $<--$ & QWL & 845 & ,081 & 10,479 & $* * *$ & \\
\hline KK1 & $<--$ & KK & 1,000 & & & & \\
\hline KK2 & $<--$ & KK & 901 & ,067 & 13,412 & $* * *$ & \\
\hline KK3 & $<--$ & KK & 801 & ,072 & 11,189 & $* * *$ & \\
\hline KK5 & $<--$ & KK & 772 & ,068 & 11,354 & $* * *$ & \\
\hline KK6 & $<--$ & KK & ,849 & ,067 & 12,595 & $* * *$ & \\
\hline KK7 & $<--$ & KK & ,949 & ,065 & 14,650 & $* * *$ & \\
\hline KK8 & $<--$ & KK & ,930 & ,073 & 12,660 & $* * *$ & \\
\hline KK9 & $<--$ & KK & ,842 & ,076 & 11,045 & $* * *$ & \\
\hline KI1 & $<--$ & $\mathrm{KI}$ & 1,000 & & & & \\
\hline KI2 & $<--$ & KI & ,902 & ,064 & 14,002 & $* * *$ & \\
\hline KI3 & $<--$ & KI & 834 & ,069 & 12,044 & $* * *$ & \\
\hline KI5 & $<--$ & KI & 808 & ,065 & 12,380 & $* * *$ & \\
\hline KI6 & $<--$ & KI & ,859 & ,065 & 13,303 & $* * *$ & \\
\hline KI7 & $<--$ & $\mathrm{KI}$ & ,950 & ,062 & 15,348 & $* * *$ & \\
\hline KI8 & $<--$ & KI & ,943 & ,071 & 13,267 & $* * *$ & \\
\hline KI9 & $<--$ & $\mathrm{KI}$ & 817 & ,072 & 11,290 & $* * *$ & \\
\hline
\end{tabular}

\section{1) Hypothesis 1}

Thevalue of the criticalratio of workload to job satisfaction is $4.84>1.96$, thus that the workload variable has a significant effect on job satisfaction indirectly. It can be concluded that hypothesis 1 states that a significant effect of workload on job satisfaction is acceptable.

\section{2) Hypothesis 2}

The critical ratio value quality of work life on job satisfaction is $5.31>1.96$, thus that thevariable quality of work life has a significant effect on job satisfaction. It can be concluded that hypothesis 2 states that the significant influence of quality of work life on job satisfaction is acceptable.

\section{3) Hypothesis 3}

Thevalue of criticaltheratio workloadto employee performance is $6.02>1.96$, thus, the workload variable has a significant effect on employee performance. It can be concluded that hypothesis 3 states that a significant effect of workload on employee performance is acceptable.

\section{4) Hypothesis 4}

The critical ratio value quality of work life on employee performance is $7.25>1.96$, thus that thevariable quality of work life has a significant effect on employee performance. It can be concluded that hypothesis 4 states that the significant influence of the quality of work life variable on employee performance variables is acceptable.

\section{5) Hypothesis 5}

Thevalue of criticalratio job satisfactionto employee performance is $7.25>1.96$, so that the job satisfaction variable has a significant effect on performance. It can be concluded 
that hypothesis 5 states that there is a significant effect of job satisfaction on performance is acceptable.

\section{Direct and Indirect Effects}

a. Direct Effect (Direct Effect) Direct effect

It is the effect indicated by one arrow on the diagram and in accordance with the given hypothesis. Below is a direct influence on this research model:

Table 9. Direct Effect

\begin{tabular}{|c|r|r|r|r|}
\hline & BK & QWL & KK & KI \\
\hline \multirow{2}{*}{ KK } & 0,276 & 0,320 & 0,000 & 0,000 \\
\cline { 2 - 5 } KI & 0,271 & 0,370 & 0,438 & 0,000 \\
\hline
\end{tabular}

From the table above shows that the direct effect of workload on job satisfaction is 0.276 while the effect of workload on job satisfaction is 0.320 , the effect of workload on employee performance is 0.271 , the effect of quality of work life on employee performance is 0.370 and the effect of job satisfaction on employee performance is 0.370 . employee performance of 0.438 .

a. Indirect Effect

Table 10. Indirect Effect

\begin{tabular}{|l|c|r|r|r|}
\hline & BK & \multicolumn{1}{c|}{ QWL } & KK & KI \\
\hline KK & 0,000 & 0,000 & 0,000 & 0,000 \\
\hline KI & 0,121 & 0,140 & 0,000 & 0,000 \\
\hline
\end{tabular}

Based on the results of the table above, the workload variable has an indirect effect on the employee performance variable of 0.121 and there is also an indirect influence of thevariable quality of work life on employee performance of 0.140 . This can prove that the effect of quality of work life on employee performance through job satisfaction is higher than the effect of workload on performance through job satisfaction $(0.140>0.121)$.

c. Total Effect

It is a sum of the results of the direct and indirect effects contained in the research model. Below are the results of the total influence on the research model:

Table 11 Total Effect

\begin{tabular}{|c|c|c|c|c|}
\hline & BK & QWL & KK & KI \\
\hline KK & 0,276 & 0,320 & 0,000 & 0,000 \\
\hline KI & 0,392 & 0,510 & 0,438 & 0,000 \\
\hline Jumlah & 0,668 & 0,83 & 0,438 & 0,000 \\
\hline
\end{tabular}

Based on the table above, the results of workload have a total effect on Job Satisfaction of 0.276 and workload has an influence on employee performance of 0.392 so that the total value reaches 0.668 . While the results of quality of work life have a total effect on job satisfaction of 0.320 and quality of work life on employee performance is 0.510 , the total value is 0.83 and the results of job satisfaction have a total effect on employee performance of 0.438 . Based on the analysis that has been done above, a score counting towards the R-Square (R2)which indicates how well the model of the proposed research. From the results of the calculation (R2), it is known that endogenous variables job satisfaction can be explained by the exogenous variables, namely the workload and quality of work life for 0501 (50.1\%) while the remaining $49.9 \%$ is explained by other exogenous variables. While the coefficient of determination of the endogenous construct of employee performance is 0.543 . These results indicate 
that the endogenous variables of employee performance can be explained by exogenous variables, namely workload, Quality of Work Life and job satisfaction of $0.543(54.3 \%)$ while the remaining $45.7 \%$ is explained by other exogenous variables outside of this study.

In addition, the research model were found to have several GOF categories or the model's due diligence value showed a fit model in the RMSEA, CMIN / DF, GFI, AGFI and TLI categories. Therefore, it can be concluded that the model as a whole can be said to be categorized as goodness of fit and marginal fit, it can be concluded that statistically the value can support according to the established fit model. Data analysis has been carried out from the conceptualization stage of the model to testing the research hypothesis. The results of the analysis can show how the role of mediation is played by job satisfaction on the relationship between workload and quality of work life and employee performance. Effect of Workload on Job Satisfaction. Based on the test results, it was found that the work satisfaction variable had a significant effect, this was because a load in the work carried out on the personnel of the National Police Headquarters was high, it would affect the satisfaction of employees.

Effect of Quality of Work Life on Job Satisfaction.

Based on the test results, it was found that the quality of work life has a positive and significant effect on job satisfaction. It can be concluded that the higher the quality of work life provided, the higher the job satisfaction of Korlantas personnel at National Police Headquarters. According to Siagian (1996), the quality of work life is a systematic effort in organizational life through workers who are also given the opportunity to find their way of working and what they provide to the organization in order to achieve its goals and objectives. The results of this study strengthen the research conducted by Sulistyowati (2019) and Santhi and Mujiati (2017) who found that quality of work life has an effect on job satisfaction.

Effect of Workload on Employee Performance.

Based on the test results, it was found that workload had an influence on work performance. It can be concluded that in a company, if the workload increases, this will affect the performance of the National Police Headquarters Korlantas employee. Polri recognizes the principle of structural loyalty and a hierarchy of command. Where the Police will remain subject to leadership, subject to hierarchy. Even though the given workload is high, it will affect the work performance of the Police Headquarters personnel.

Effect of Quality of Work Life on Employee Performance

Based on the test results, it was found that the quality of work life has a positive and significant effect on employee performance. It can be concluded that the higher the quality of work life provided, the higher the employee performance of Korlantas personnel at the National Police Headquarters. The results of this study reinforce the research conducted by Ainul \& Rahman (2020), Alfani (2018) who found that quality of work life has an effect on employee performance.

Influence Job Satisfaction on Employee Performance.

Based on the test results, it was found that job satisfaction has a positive and significant effect on job performance. It can be concluded that the higher the existing job satisfaction, the higher the employee performance of Korlantas personnel at the National Police Headquarters. The results of this study reinforce the research conducted by Tsai1 et al. (2018) and Durrah et al. (2016) who found that job satisfaction has an effect on employee performance. 
Effect of Workload on Employee Performance through Job Satisfaction as an intervening variable.

Based on the test results in this study, it was found that the intervening variable or job satisfaction variable bridges the indirect effect of the workload variable $(X)$ on employee performance $(\mathrm{Y})$. Thus it can be formulated that "The higher the workload on employees of the Korlantas personnel at the Indonesian Police Headquarters, the job satisfaction will be achieved in accordance with the predetermined vision and mission. If the higher the job satisfaction, the employee's performance will be better.

The influence of Quality of Work Life on Employee Performance through Job Satisfaction as an intervening variable.

Based on the results of research that has been done, that job satisfaction bridges the indirect influence of the variable quality of work life $(X)$ on employee performance (Y). It can be concluded that if the quality of work life of the employees of the National Police Corps of the Republic of Indonesia is getting higher, the employees will feel job satisfaction, and the higher the job satisfaction, the employees will improve their performance in work. This hypothesis testing stage is carried out after the structural model evaluation stage is carried out. This stage is carried out to determine whether the research hypothesis proposed in the research model is accepted or rejected. To test the proposed hypothesis, it can be seen from the estimated value, the critical ratio value and the P-Value.

The results of testing the first hypothesis show a p-value of $0.846>0.05$, so these results indicate that $\mathrm{H} 0$ is supported and $\mathrm{Ha}$ is not supported, which means that there is no influence between workload on job satisfaction. The estimate value was found to be 0.007 (positive effect) while the critical ratio (CR) value was $0.194<1.96$. These results prove that the first hypothesis is rejected. The results of testing the second hypothesis show a p-value of $0.000<0.05$, so these results indicate that $\mathrm{H} 0$ is not supported and Ha is supported, which means that there is an influence between quality work of life on job satisfaction. The estimate value was found to be 0.524 (positive effect) while the critical ratio (CR) value was $8.349>1.96$. These results prove that the second hypothesis is accepted.

The results of testing the third hypothesis show a p-value of $1.485>0.05$, so these results indicate that $\mathrm{HO}$ is supported and $\mathrm{Ha}$ is not supported, which means that there is no influence between workload on employee performance. The estimate value was found to be 0.058 (positive effect) while the critical ratio (CR) value was 1.485 $<1.96$. These results prove that the third hypothesis is rejected. The results of testing the fourth hypothesis show a p-value of $0.000<0.05$, so these results indicate that $\mathrm{H} 0$ is not supported and Ha is supported, which means that there is an influence between quality work of life on job satisfaction. The estimate value was found to be 0.332 (positive effect) while the critical ratio (CR) value was 5.471> 1.96. These results prove that the fourth hypothesis is accepted. The results of testing the fifth hypothesis show a p-value of $0.000<0.05$, so these results indicate that $\mathrm{HO}$ is not supported and $\mathrm{Ha}$ is supported, which means that there is an influence between job satisfaction and job satisfaction. The estimate value was found to be 0.445 (positive effect) while the critical ratio (CR) value was $4.983>1.96$. These results prove that the fifth hypothesis is accepted.

Indirect hypothesis testing or mediation is carried out by the method developed by Sobel (1982) and is known as the Sobel test (Ghozali, 2011). The Sobel test is done by testing the strength of the indirect effect of the independent variable on the dependent. The results of the sixth hypothesis testing through the sobel test showed that the sobel 
p-value was $0.845>0.05(\alpha=10 \%)$, the aroian was $0.848>0.05(\alpha=10 \%)$ and the goodment test was $0.842>0.05(a=10 \%)$, then These results indicate that $\mathrm{HO}$ is supported and Ha is not supported, which means that job satisfaction does not mediate the relationship between workload and employee performance.

The results of the seventh hypothesis testing through the sobel test showed that the sobel p-value was $0.000>0.05(\alpha=10 \%)$, the aroian was $0.000>0.05(\alpha=10 \%)$ and the goodment test was $0.000>0.05(\alpha=10 \%)$, then These results indicate that $\mathrm{H} 0$ is not supported and $\mathrm{Ha}$ is supported, which means that job satisfaction mediates the relationship between quality work of life and employee performance. Job satisfaction is a pleasant emotional state or general attitude towards differences in rewards received on job indicators, adjustment and individual social relations outside of work (Gitosudarmo, 1997). Cormick \& Ilgen (1980) stated that job satisfaction is a person's attitude towards their job. In other words, job satisfaction is a person's affective response to work. Another view of job satisfaction is that the individual calculates the extent to which the job produces valuable results. It is assumed that individuals have a number of judgments about how much they value certain outcomes such as salary, promotion or good working conditions. Meshkati in Hariyati (2011) states that workload is a difference between the capacity or ability of workers and the job demands that must be faced. Considering that human work is mental and physical, each has a different level of burden. The loading level that is too high allows excessive energy use and overstress, on the other hand, the intensity of the loading is too low to allow boredom and boredom. Therefore it is necessary to strive for an optimum level of intensity of loading that exists between the two extreme limits and of course it differs from one individual to another. Workload is influenced by job satisfaction. High workload has a negative effect on job satisfaction Mustapha \& Ghee (2013). In the research of Mustafa (2013) states that job satisfaction affects daily workload, employees are more satisfied when they are given a lower workload. Research conducted by Yo and Surya (2015) entitled "The Effect of Workload on Job Satisfaction with Job Stress as an Intervening Variable". This research was conducted at PT. Lianinti Abadi Denpasar with 55 respondents. Path analysis used in hypothesis analysis. The purpose of this study was to determine the influence of workload on satisfaction with stress as an intervening variable. The result of this study is that workload has a negative effect on employee satisfaction. Research conducted by Abbasi (2015) entitled "Impact work Overload on Stress, Job Satisfaction, and Turnover Intentions with Moderating Role of Islamic Work Ethics". This research was conducted at PT. Azad Jammu and Kashmir with a sample of 123 . The aim of the study was to see the effect of excessive workloadsn dilemma in almost every industrial sector. The result of this research is workload has a negative effect on employee job satisfaction. According to Harold at. al. (1990) Quality work life is a systems approach to job design and development in a broad scope, especially in job enrichment. This quality work life approach is combined with a socio-ethnic systems approach in management. Therefore, quality work life is not only an approach to job enrichment but also a multidisciplinary field and a combination of industrial and psychological disciplines, industrial engineering, organizational theory, motivation, leadership, and industrial relations. Research conducted by Bekti (2018) entitled "The Effect of Quality of Work Life on Job Satisfaction of Employees at X Hospital Surabaya". The population in this study were all employees who worked at X Hospital Surabaya. The sample size was calculated using the simple random sampling method from Lemeshow. The results of the calculation were obtained as many as 57 respondents. The determination of the sample 
size for each work unit was obtained by using the proportional random sampling method. The results of this study state that the quality of work life affects job satisfaction. Research conducted by Lefiandra and Suwarsi (2019) entitled "The Effect Of Quality work life On Employee Job Satisfaction (Case Studies on PT. Bank Mandiri (Persero) Tbk, Bandung)". This study used a sample of 50 people using field research data collection techniques and library research. The results of this study explain that the quality of work life affects employee satisfaction. Based on references from previous research journals and also adapted to the conditions of the research object, the hypothesis proposed in this study are:

H1 : Workload has positive and significant effect on job satisfaction.

H2 : Quality work life has positive and significant effect on job satisfaction.

H3 : Workload has positive and significant effect on performance.

H4 : Quality work life has positive and significant effect on performance.

H5 : Satisfaction has positive and significant effect on performance.

H6 : Workload has positive and significant effect on performance through job satisfaction.

H7 : Quality work life has positive and significant effect on performance through job satisfaction.

Data analysis has been carried out from the conceptualization stage of the model to testing the research hypothesis. The results of the analysis can show how the role of mediation is played by job satisfaction on the relationship between workload and quality of work of life and employee performance. The Effect of Workload on Job Satisfaction. Based on the test results, it was found that workload has no effect on job satisfaction. It can be concluded that the increase or decrease in workload does not affect the job satisfaction of Korlantas personnel at the National Police Headquarters. Even though the given workload is high, it will not affect the job satisfaction of the Police Headquarters personnel (Sewell \& 2015). The results of this study reinforce research conducted by Nadeem (2009) who found that workload does not affect employee job satisfaction. The Effect of Quality Work of Life on Job Satisfaction Based on the test results, it was found that the quality of work of life has a positive and significant effect on job satisfaction. It can be concluded that the higher the quality of work life provided, the higher the job satisfaction of Korlantas personnel at National Police Headquarters (Noor \& Abdullah, 2012). According to Siagian (1996), the quality of work life is a systematic effort in organizational life through workers who are also given the opportunity to find their way of working and what they provide to the organization in order to achieve its goals and objectives. The results of this study strengthen the research conducted by Sulistyowati (2019) and Santhi \&Mujiati (2017) who found that quality work of life has an effect on job satisfaction. The Effect of Workload on Employee Performance. Based on the test results, it was found that workload had no effect on work performance. It can be concluded that the increase or decrease in workload does not affect the performance of employees of Korlantas personnel at the National Police Headquarters.

Indonesian Police recognizes the principle of structural loyalty and a hierarchy of command that the Police will remain subject to leadership, subject to hierarchy. Even though the given workload is high, it will not affect the work performance of the Police Headquarters personnel. The results of this study reinforce the research conducted by Qoyyimah et al., (2019) and Chandra \&Adriansyah (2017) who found that workload does not affect employee performance. The Effect of Quality Work of Life on Employee 
Performance. Based on the test results, it was found that the quality of work of life has a positive and significant effect on work performance. It can be concluded that the higher the quality of work life provided, the higher the employee performance of Korlantas personnel at the National Police Headquarters. The results of this study reinforce the research conducted by Ainul \& Rahman (2020) and Alfani (2018) who found that quality work of life affects employee performance. The Effect of Job Satisfaction on Employee Performance Based on the test results, it was found that job satisfaction has a positive and significant effect on job performance. It can be concluded that the higher the existing job satisfaction, the higher the employee performance of Korlantas personnel at the National Police Headquarters. The results of this study reinforce the research conducted by Tsail et al. (2018) and Durrah et al. (2016) who found that job satisfaction has an effect on employee performance. The Effect of Workload on Employee Performance through Employee Satisfaction. Based on the test results on the mediating effect of job satisfaction on the relationship between workload and employee performance, it was found that job satisfaction did not have a mediating effect. Whether or not job satisfaction exists in the relationship between workload and employee performance has no effect and is not a connecting variable between endogenous and exogenous variables. The results of this study contradict research conducted by Lukiyana \& Firdaus (2017) which found that job satisfaction can mediate the relationship between workload and performance. The Effect of Quality Work of Life on Employee Performance through Employee Satisfaction. Based on the test result on the mediating effect of job satisfaction on the relationship between the quality work life on employee performance, it is found that job satisfaction has a mediating effect. With the support of job satisfaction in the relationship of quality work of life to employee performance, it is able to encourage increased employee performance and is a connecting variable between endogenous and exogenous variables. The results of this study are in line with research conducted by Sari, Bendesa and Antara (2019) who found that job satisfaction can mediate the relationship between quality work of life and performance.

\section{CONCLUSIONS}

Based on the results of hypothesis testing and the discussion stated in the previous chapter, several conclusions can be obtained as follows: The workload has no effect on job satisfaction of the personnel of the National Police Headquarters Traffic Corps. This proves that the workload factor that exists does not have a direct role in encouraging job satisfaction of personnel from Korlantas at the National Police Headquarters. Quality work of life has positive and significant effect on job satisfaction of personnel from the National Police Headquarters Corps. This proves that the existing work of life quality factor has a direct role in encouraging job satisfaction of the personnel of Korlantas at the National Police Headquarters. The workload has no effect on the performance of the personnel of the Police Headquarters Korlantas personnel. This proves that the existing workload factor does not have a direct role in encouraging the performance of employees of Korlantas personnel at the National Police Headquarters. Quality work of life has positive and significant effect on job satisfaction personnel Korlantas Police Headquarters. This proves that the work of life quality factor that exists has a direct role in encouraging the performance of employees of Korlantas personnel at the National Police Headquarters. Job satisfaction has positive and significant effect on job satisfaction of the personnel of Korlantas at the National Police Headquarters. This proves that the work of life quality factor that exists 
has a direct role in encouraging the performance of employees of Korlantas personnel at the National Police Headquarters. Job satisfaction does not mediate the relationship between workload and employee performance. This proves that the job satisfaction factor of Korlantas personnel at National Police Headquarters does not have a direct role in driving workloads with employee performance. Job satisfaction mediates the relationship between quality work of life and employee performance. This proves that the job satisfaction factor of Korlantas personnel at National Police Headquarters has a direct role in encouraging quality work of life with employee performance. Researchers suggest to further researchers to add other exogenous variables outside of this study. Given the value of R-Square (R2) for endogenous variables customer satisfaction is still at $50.1 \%$ and endogenous variables employee performance is $54.3 \%$. It is expected that by adding other variables, the coefficient of determination can increase.

\section{ACKNOWLEDGEMENTS}

The researchers expressed our gratitude and appreciation for the trust that has been given by Universitas Negeri Jakarta.

\section{AUTHOR CONTRIBUTION STATEMENTS}

First author had contribution for collecting data in this research. Corresponding author was a corresponding person with editor, from submission until publish for this article. Another authors help to improve this research paper before submit to journal.

\section{REFERENCES}

Abbasi, I. S., \& Alghamdi, N. G. (2015). The Prevalence, Predictors, Causes, Treatments, and Implications of Procrastination Behaviors in General, Academic, and Work Setting. International Journal of Psychological Studies, 7 (1), 59-66. Google Scholar Adityawarman, Sanim, Sinaga (2015). Jurnal Manajemen dan Organisasi Vol.VI No.1 Pengaruh Beban Kerja Terhadap Kinerja Karyawan PT. Bank Rakyat Indonesia (persero) Tbk Cabang Krekot. https:/ / doi.org/10.29244/jmo.v6i1.12182

Agripa Toar Sitepu (2013), Beban Kerja Dan Motivasi Pengaruhnya Terhadap Kinerja Karyawan Pada Pt. Bank Tabungan Negara Tbk Cabang Manado, Fakultas Ekonomi dan Bisnis, Jurusan Manajemen, ISSN 2303-1174 Vol.1 No.4. https:// doi.org/10.35794/emba.v1i4.2871

Ahmad, Komarudin. 1996. Dasar-dasar Manajemen Investasi. Jakarta : Rineka. Cipta.

Ainul Hadi, H. R. (2018). Pengaruh Psychological Capital Terhadap Kinerja Dan

Turnover Intention Karyawan Ngo X Dengan Quality Of Work Life Sebagai Variabel Mediasi. Ilmiah Mahasiswa Ekonomi Manajemen, Vol. 3, No. https:// doi.org/10.24815/jimen.v3i4.9792

Ainul Hadi, H. R. (2020). Analisis Pengaruh Quality Of Work Life, Motivasi Berprestasi

Dan Kepemimpinan Transformasional Terhadap Kinerja Guru. Inovasi Pembelajaran Karakter (JIPK), Vol. 5, No. Google Scholar

Al.; M.-C. T. et. (2010). Drivers of hospitality industry employees job satisfaction, organizational commitment and job performance. African Journal of Business Management. https://doi.org/10.5897/AJBM.9000227

Alfani, H. M. (2018). Analisis Pengaruh Quality Of Work Life (QWL) Terhadap Kinerja Dan Kepuasan Kerja Karyawan PT. Bank BRI Syariah Cabang Pekanbaru. Jurnal Tabarru' : Islamic Banking and Finance, I(I). https://doi.org/10.25299/jtb.2018.vol1(1).2039 
Alfani, M. H. (2018). Analisis Pengaruh Quality Of Work Life (QWL) Terhadap Kinerja dan Kepuasan Kerja Karyawan PT. Bank BRI Syariah Cabang Pekanbaru. Jurnal Tabarru': Islamic Banking and Finance. https:// doi.org/10.25299/jtb.2018.vol1(1).2039

Ali , M. B. 2002. Kamus Bahasa Indonesia, Penabur Ilmu, Bandung. Googe Scholar

Almadina Nurfitri Lefiandra, S. S. (2019). Pengaruh Kualitas Hidup Kerja (Quality Of Work Life) Terhadap Kepuasan Kerja (Studi Kasus pada PT. Bank Mandiri (Persero) TBK, Bandung).

Altaf, A., \& Awan, M. A. 2011.Moderating affect of workplace spirituality on the relationship of job overload and job satisfaction. Journal of business ethics,104(1).

Bekti, R. R. (2018). Pengaruh Kualitas Kehidupan Kerja Terhadap Kepuasan Kerja Karyawan Rumah Sakit Ibu dan Anak X Surabaya. Jurnal Administrasi Kesehatan Indonesia. https:// doi.org/10.20473/jaki.v6i2.2018.156-163

Brown, S. P., Jones, E., \& Leigh, T. W. (2005). The Attenuating Effect of Role Overload on Relationship Linking Self-Efficacy and Goal Level to Work Performance. Journal of Applied Psychology, 90(5) 972-979.

Budiyarti , 2007, Manajemen Kinerja, Rajawali Pers, Jakarta.

Cascio Wayne , 2001, Motivation and Personality, American Management Association, New York.

Church, A. H. (1995). Managerial behaviors and work group climate as predictors of employee outcomes.

Clifford P. McCue and Gerasimos A. Gianakis, 1997, “The Relationship Between Job Satisfaction and Performance, The Case Local Government Finance Officers in Ohio", Public Productivity \& Management Review, Vol 21 No. 2 December.

Colquitt. Jason. A, Lepine. Jeffery. A dan Wesson. Michael. J. 2015. Organizational Behavior, 4 thed, McGraw - Hill Education, United States of America.

de Menezes, L. M. (2012). Job satisfaction and quality management: An empirical analysis. International Journal of Operations and Production Management. https:// doi.org/10.1108/01443571211212592

Dessi Wahyu Hersanti, Gunistiyo, D. N. R. (2020). Analisis Pengaruh Quality of Work Life, Motivasi Berprestasi dan Kepemimpinan Transformasional Terhadap Kinerja Guru. Inovasi Pembelajaran Karakter (JIPK), Vol. 5, No.

Dessler, Gary. 2015. Manajemen Sumber Daya Manusia. Jakarta: Salemba Empat.

Dole, Carol and Schroeder, Richard G.,2001, The Impact of Varios Factors on the Personality, Job Satisfaction and Turn Over Intention of Profesional Accountants, Managerial Auditing Journal, Vol. 16 No.4 pp 234-245.

Drivers of hospitality industry employees job satisfaction, organizational commitment and job performance. (2010). African Journal of Business Management.

Durrah, O., Alhamoud, A., \& Khan, K. (2016). Positive psychological capital and job performance: The mediating role of job satisfaction. Ponte. https://doi.org/10.21506/j.ponte.2016.7.17

Durrah, Omar dkk. 2016. Exploring the Relationship between Liquidity Ratios and Indicators of Financial Performance: An Analytical Study on Food Industrial Companies Listed in Amman Bursa. International Journal of Economics and financial Issues. Vol. 6, No.2

Durrah, Omar, Abdul Aziz Abdul Rahman, Syed Ahsan Jamil, and Nour Aldeen Ghafeer. 2016. "Exploring the Relationship between Liquidity Ratios and Indicators of Financial Performance: An Analytical Study on Food Industrial 
Companies Listed in Amman Bursa." International Journal of Economics and Financial Issues 6(2): 435-41.

Eko Nurmianto, Nurhadi Siswanto. 2006. Perancangan Penilaian Kinerja Karyawan Berdasarkan Kompetensi Spencer Dengan Metode Analytical Hierarchy Process. Jurnal teknik industri vol. 8, no. 1, juni 2006: 40-53.

Engko, Cecilia. 2008. "Pengaruh Kepuasan Kerja Terhadap Kinerja Individual Dengan Self Esteem dan Self Efficacy Sebagai Variabel Intervening". Jurnal Bisnis dan Akuntansi Vol. 10, No. 1, April.

Essiam, J., Mensah, M. E., Kudu, L. K., \&Gyamfi, G. D. (2015).Influence of Job Stress on Job Satisfaction Among University Staff : Analytical Evidence From a Public University in Ghana. International Journal of Economics, Commerce and Managementn, 3(2), 1-15.

Firdaus, Ahmad Fathiyah dan Alex Kurnia Putra. 2017. Pengaruh komitmen kerja dan quality of work life terhadap kepuasan kerja dan dampaknya terhadap kinerja karyawan. Jurnal MAS Vol. 2 No. 1 Hal. 105-120.

Fred Luthans, (2006), Perilaku Organisasi. Edisi Sepuluh, PT. Andi: Yogyakarta.

Gahlan, H. A., Azer, M. K., \& Khalil, A. E. S. (2015). The Neoproterozoic Abu Dahr ophiolite, South Eastern Desert, Egypt: petrological characteristics and tectonomagmatic evolution. Mineralogy and Petrology. https://doi.org/10.1007/s00710-015-0397-z

Gitosudarmo, Indriyo dan Sudita, I Nyoman. 1997, Perilaku Keorganisasian, Yogyakarta : BPFE.

Greogy Moorhead dan Ricky W. Griffin.2013." Perilaku Organisasi Manajemen Sumber Daya Manusia dan Organisasi “ edisi 9. Jakarta.Salemba empat.

Hadi1, A., \& Hafiz Rahman2. (2018). Pengaruh Psychological Capital Terhadap Kinerja dan Turnover Iintention Karyawan Ngo X Dengan Quality of Work Life sebagai Variabel Mediasi. Ilmiah Mahasiswa Ekonomi Manajemen, Vol. 3, No.

Hair et al., (1998), Multivariate Data Analysis, Fifth Edition, Prentice Hall, Upper Saddle River : New Jersy.

Hannani, A., Muzakkir, \& Ilyas, G. B. (2016). Pengaruh Beban Kerja, Kepuasan, Dan Fasilitas Terhadap Kinerja Perawat Di Ruang Perawatan Mawar Lantai II RSU Wisata UIT Makassar. Jurnal Mirai Management.

Hart, S. G., \& Staveland, L. E. (1981). Development of NASA-TLX (Task Load Index Results of Empirical and Theoretical Research. In Human Mental Workload, 139- 183.

Hart, S.G. dan Staveland,L.E., 1988, Development of NASA Task Load Index (TLX): Results of Empirical and Theoritical Research, NASA-Ames Research, California.

Hartono,Jogiyanto.2016. Teori Portofolio dan Analisis Investasi. Edisi Kesepuluh.Yogyakarta.

Hasibuan, Malayu. 2012. "Manajemen Sumber Daya Manusia". Jakarta: PT Bumi Aksara. Hettiararchchi, H. A. ., \& Jayarathna, S. M. D. . (2014). The effect of Employee Work Related Attitudes on Employee Job Performance: A Study of Tertiary and Vocational Education Sector in Sri Lanka. IOSR Journal of Business and Management. https:// doi.org/10.9790/487x-16447483

Iroegbu, Manasseh. (2014). Personality and Gender: A Meta - Analysis of Their Effects on Employee Stress. University Of Uyo And Imo State Univeristy. G.J.I.S.S.,Vol.3(6):63-65. 
Iskandar, S. (2012). Pengaruh Beban Kerja, Motivasi Dan Kepuasan Kerja Terhadap Kinerja Pegawai Bank BJB Cabang Padalarang. Jurnal Ekonomi, Bisnis $\mathcal{E}$ Entrepreneurship.

Iskandar, Sentot dan Gredi Granada Sembada. 2012. Pengaruh Beban Kerja, Motivasi dan Kepuasan Kerja Terhadap Kinerja Pegawai Bank BJB Cabang Padalarang. Jurnal Ekonomi, Bisnis \& Entrepreneurship Vol. 6, No.1, April 2012, 26-38 ISSN 2443-0633.

Kanten S. \& Sadullah O. (2012) An empirical research on relationship quality of work life and work engagement. Procedia - Social and Behavioral Science, 62. 360-366.

Kanten, Selahattin. Sadullah, Omer. (2012). An empirical research on relationship quality of work life and work engagement. Proceida-Social and Behavioral Sciences. 62(2012) 360-366.

Koonts, Harold, Cyril O'Donnell, dan Heinz Weihrich. (1990). Manajemen. Alih Bahasa Antarikso. Erlangga: Jakarta.

Kossen, Stan. (1993). Aspek Manusiawi dalam Organisasi. Erlangga. Jakarta.

Ladebo, O. J., \& Awotunde, J. M. (2007). Emotional and behavioral reactions to work overload: Self-efficacy as a moderator. Current Research in Social Psychology.

Ladebo, O. J., \& Awotunde, J. M. (2007). Emotional and behavioral reactions to work overload: Self-efficacy as a moderator. Current Research in Social Psychology.

Lee M. Ozley dan Yudith S. Ball, 1992. Quality of Work Life: Initiating Success Full Effort in Labor Management Organization, Jurnal Personnel Administrator, 27 May 1982.

Lia Amalia. (2017). Pengaruh Beban Kerja Dan Komitmen Terhadap Kinerja Dan Kepuasan Kerja Perawat Sebagai Variabel Intervening Pada Rumah Sakit Tabrani RAB Pekanbaru. Jurnal Online Mahasiswa Fakultas Ekonomi Universitas Riau. https:// doi.org/10.1017/CBO9781107415324.004

Lilian M. de Menezes (2012), Job satisfaction and quality management: an empirical analysis, International Journal of Operations \& Production Management, Vol. 32 Issue: (3), pp.308-328.

Lukiyana, dan Firman Davi Firdaus. 2017. “Pengaruh Beban Kerja Dan Lingkungan Kerja Terhadap Prestasi Kerja Karyawan Dengan Kepuasan Kerja Sebagai Variabel Intervening Di Bagian Gudang Pada Pt. Sarijasa 20 Transutama Jakarta". ISSN 1411-0830. Volume 14. Universitas 17 Agustus 1945 Jakarta.

McCormick, Ernest J. dan Daniel R. Ilgen. 1980. Industrial Psychology - 7th ed. Prentice-Hall Inc.

Mustapha, Noraani dan Ghee, W. Y. 2013. Examiningi Faculty Workloadias Antencedent of Job Satisfaction among Academic Staff of Higher Public Education on Kelantan, Malaysia. Journal Business and Management Horizons, 1(1), pp: 10-16.

Noor, S. M., \& Abdullah, M. A. (2012). Quality Work Life among Factory Workers in Malaysia. Procedia - Social and Behavioral Sciences. https://doi.org/10.1016/j.sbspro.2012.02.144

Pasaribu, Evan Karno dan Indrawati, Ayu Desi. 2016. Pengaruh Iklim Organisasi dan Kualitas Kehidupan Kerja terhadap Kinerja Pegawai Dinas Sosial Provinsi Bali. e-Jurnal Manajemen UNUD, Volume 5, Nomor 12, 2016.

Putra, Nusa.2012. Metode Penelitian Kualitatif Pendidikan. Jakarta : Rajagrafindo Persada.

Robbins, P. Stephen. (2003). Perilaku Organisasi. Edisi Sembilan, Jilid 2. Edisi Bahasa Indonesia. PT Indeks Kelompok Gramedia, Jakarta. 
Robbins, P. Stephen. (2003). Perilaku Organisasi. Edisi Sembilan, Jilid 2. Edisi Bahasa Indonesia. PT Indeks Kelompok Gramedia, Jakarta.

Robbins, Stephen P \& Judge, Timothy A. 2013. Organizational Behavior Edition 15. New Jersey: Pearson Education.

Sari, N. P. R., Bendesa, I. K. G., \& Antara, M. (2019). The Influence of Quality of Work Life on Employees' Performance with Job Satisfaction and Work Motivation as Intervening Variables in Star-Rated Hotels in Ubud Tourism Area of Bali. JOURNAL OF TOURISM AND HOSPITALITY MANAGEMENT. https://doi.org/10.15640/jthm.v7n1a8

Sewell, B. B., \& Gilbert, C. (2015). What Makes Access Services Staff Happy? A Job Satisfaction Survey. Journal of Access Services, 12(3-4), 47-74. https:// doi.org /10.1080/15367967.2015.1061435.

Sutrisno. (2012). Manajemen Keuangan Teori, Konsep dan Aplikasi (8thed.). Yogyakarta: Ekonisia.

Tsai, M.C., Cheng, C.C., dan Chang, Y.Y. (2010). Drivers of hospitality industry employees' job satisfaction, organizational commitment and job performance. African Journal of Business Management. Vol.4(18), pp.4118-4134

Tsai, Y. C. \& Yeh. J.C. (2010). Perceived risk of information security and privacy in online shopping: A study of environmentally sustainable products. African Journal of Business Management Vol. 4(18), pp. 4057-4066

Wahyuni, R., \& Irfani, H. (2019). Pengaruh Kompensasi Dan Beban Kerja Terhadap Kepuasan Kerja Dalam Meningkatkan Kinerja Karyawan Pt. Kepsindo Indra Utama Padang. Jurnal PSYCHE 165 Fakultas Psikologi.

Wahyuni, R., Irfani, H., \& Syahrina, I. A. (2019). Pengaruh Gaya Hidup Dan Literasi Keuangan Terhadap Perilaku Konsumtif Berbelanja Online Pada Ibu Rumah Tangga Di Kecamatan Lubuk Begalung Kota Padang. Benefita, 4(3), 548-559.

Wibowo. 2009. Manajemen Kinerja. Jakarta: Raja Grafindo.

Copyright Holder :

(C) Wirastuti, S., Sudiarditha, I., Eryanto, H., Susono, J., \& K, Amiruddin. (2020)

First Publication Right :

(C) IJoASER (International Journal on Advanced Science, Education, and Religion)

This article is under:

CC BY SA 